\title{
Mineralogical and thermodynamic constraints on Palaeogene palaeotemperature conditions during low-grade metamorphism of basaltic lavas recovered from the Lopra-1/1 A deep hole, Faroe Islands
}

\author{
William E. Glassley
}

The sequene of secondary minerals that are reported for the Lopra-1/1A well records progressive zeolite facies to prehnite-pumpellyite-facies mineral progressions consistent with those of other wellstudied hydrothermally altered rock sequences. Detailed comparison of the calc-silicate (zeolites and prehnite) mineral distributions of the Lopra-1/1A sequence with those from other regions indicates that this sequence exhibits consistently longer down-hole intervals for secondary mineral species than reported elsewhere. When compared to measured down-hole temperatures reported in other hydrothermally altered regions, the results suggest that the Lopra-1/1A mineral progression formed under conditions typical of low temperature hydrothermal systems that form shortly after eruption of thick basaltic piles. Maximum temperatures achieved at the $3500 \mathrm{~m}$ level of the well were at or below $200^{\circ} \mathrm{C}$. The implied geothermal gradient was less than $50^{\circ} \mathrm{C} / \mathrm{km}$. An analysis of prehnite - fluid composition relationships was also conducted in order to determine if results compatible with the paragenetic sequence study could be obtained from thermodynamic constraints. In this case, the limiting temperature for prehnite formation in equilibrium with albite-quartz-calcite-laumontite (the mineral assemblage at the bottom of the hole) was determined for a range of fluid compositions. The resulting calculations suggest temperatures of formation of prehnite in the range of $140^{\circ} \mathrm{C}$ to $205^{\circ} \mathrm{C}$, a conclusion which is broadly consistent with those reached from study of the paragenetic relationships. Comparison of these results with other studies of palaeogeothermal gradients of the North Atlantic margins suggests a consistent pattern in which relatively low geothermal gradients persisted in the Palaeogene rift basin.

Keywords: North Atlantic Volcanic Province, thermal history, geothermal gradients, low temperature metamorphism, fluid-rock interaction, reactive transport, zeolites, prehnite-pumpellyite

Lawrence Livermore National Laboratory, Livermore, California 94550, USA. E-mail: glassley1@llnl.gov

Minerals that crystallise from basalticlavas are unstablewith respect to a wide range of hydrous silicates and carbonates when subjected to low temperature conditions $\left(<300^{\circ} \mathrm{C}\right)$ in the presence of $\mathrm{H}_{2} \mathrm{O}$ - and $\mathrm{CO}_{2}$-bearing fluids. Recrystallisation of basaltic rocks under these physical and chemical conditions results in the development of minerals that characterise the zeolite, prehnite-pumpellyite and greenschist facies. It has been well-documented that the basalts of the East Greenland - Faroe Islands province record ex- tensive development of minerals characteristic of the zeolite and lower prehnite-pumpellyite facies (Jørgensen 1984, 1997; Neuhoff et al. 1997; Larsen et al. 1999). What remains unclear is the temperature history recorded by these mineral assemblages.

Generally, under the lowest temperature conditions, clays, zeolites and hydrous $\mathrm{Fe}-\mathrm{Mg}$ silicates form, giving way to less hydrated minerals at higher temperatures. Often this progression is recorded by the presence of a 
complex sequence of zeolite minerals that have increasingly smaller amounts of molecular water bound in their structures (Bird et al. 1984; Neuhoff \& Bird 2001). In principle, therefore, zeolitic and related minerals can be sensitive indicators of temperature conditions.

This temperature sensitivity is complicated by the equally important sensitivity of the zeolites to the composition of coexisting fluids. The thermodynamic properties of the zeolites are affected by substitution between the alkali metals, particularly $\mathrm{Na}, \mathrm{K}$ and $\mathrm{Ca}$, and $\mathrm{Al}-\mathrm{Si}$ exchange (e.g. Neuhoff et al. 1997, 2002, 2003, 2004). The stability fields of the zeolites are also sensitive to the ratio of calcium activity to hydrogen ion activity (i.e. $[\mathrm{Ca}++] /[\mathrm{H}+]^{2}$ ) in the coexisting fluid phase (e.g. Surdam 1973; Bird et al. 1984). Hence, fluid chemistry has a strong influence on both the mineral compositions that develop and the specific mineral phases that form during low temperature recrystallisation.

The purpose of this paper is to define likely bounds for bottom-hole temperatures and the likely geothermal gradient active at the time of mineral development, based on paragenetic relationships and thermodynamic constraints, taking into account the effects of fluid chemistry. Detailed descriptions of the locations, mineralogies and geological settings for the Lopra-1/1A and Vestmanna-1 boreholes are presented in other chapters in this book and are only summarised here.

\section{Geology}

The basalts of the Faroe Islands were erupted subaerially onto continental crust during opening of the northern North Atlantic. The basalts have been divided informally into an upper, a middle and a lower formation. The lower basaltic sequence is more than $3000 \mathrm{~m}$ thick (established on the basis of field exposure and the Lopra-1/1A drilling programme), and ranges in age from c. 58.8 to $56.5 \mathrm{Ma}$ (Waagstein et al. 2002). The overlying basalts and sediments (some of the sediments are coal-bearing) are more than $2000 \mathrm{~m}$ thick and were erupted between $c .56$ and $55.5 \mathrm{Ma}$ (Larsen et al. 1999). Recrystallisation of the lavas took place during subsequent burial, leading to the development of a wide range of zeolites and associated calc-silicate minerals (Jørgensen 1984, 1997). The argument that the secondary mineral development results from burial metamorphism, rather than significant tectonic stacking or folding, is based on the relatively flat-lying nature of the basaltic flows and the absence of any kinematic fabric.

\section{Methods}

\section{Compiled published data}

Published data from active hydrothermal systems where temperatures and mineral associations are recorded, provide the most direct evidence of the conditions under which specific mineral assemblages occur. For this reason, published data from a variety of drilled hydrothermal systems with depths less than $4000 \mathrm{~m}$ were analysed to identify temperature constraints that would apply to the mineral associations reported for samples from the Lopra-1/1A drilling programme(Jørgensen 1984, 1997). The reported Lopra-1/1A assemblages were confirmed by the author during independent examination of thin sections.

The best available data that correlate downhole temperatures, depth and mineral occurrences are from geothermal systems in Iceland (Kristmannsdóttir \& Tomassón 1976), Japan (Seki et al. 1969; Boles 1981), Cerro Prieto (Bird et al. 1984), Wairakei (Steiner 1977) and Toa Baja (Cho 1991). The reports from Iceland and Japan discuss secondary mineral development related to alteration of basaltic rocks, which most closely correspond to the Lopra1/1A sequence. The Cerro Prieto locality consists of sedimentary rocks (sandstones, siltstones and mudstones) that are predominately composed of quartz and feldspars. The Wairakei and Toa Baja localities consist of volcanic and volcanoclastic rocks and their associated clastic derivatives. The Wairakei rocks are primarily rhyolitic and the Toa Baja rocks primarily andesitic.

This suite of rock types spans the entire range from basalts through andesites to rhyolites, thus encompassing silica-poor to silica-rich compositions with varying abundances of alkali metals. On a whole-rock basis, then, the compositional range from these reported systems bounds that of the Faroe Island basalts considered here.

The different tectonic settings represented by these systems include both rift and convergent margin environments. Since these different settings evolved through different thermal histories, it is likely that the possible thermal conditions that may have affected the Faroe Island basalts, will be represented by at least some of the data recorded in the published studies.

The range of fluid compositions at the various sites is broad. The Cerro Prieto fluids were concentrated solutions with high total dissolved solids and salinities, while many of the solutions reported from the New Zealand region, particularly within the Broadlands-Ohaki (Hedenquist 1990) and Wairakei areas, included $\mathrm{CO}_{2}$-rich and neutral-pH chloride waters and $\mathrm{CO}_{2}$-poorer fluids occurred within the Iceland system. Thus, the published re- 
ports examined include a range of solutions that are likely to encompass those that may have been present during alteration of the Faroe Island basalts.

Clear differences exist between sites with regard to the depth and extent of secondary mineral development, reflecting the effects of these combined intensive and extensive variables (i.e. T, bulk composition, fluid composition etc.). By considering this broad range of systems, it is possible to develop some insight into the extent to which differing geothermal and chemical conditions influenced the development of the mineral associations and how that influence is expressed at the Lopra-1/1A site. Comparison of the Lopra-1/1A suite with these reported mineral parageneses should provide a strong bound to the thermal gradient inferred from these data.

In this study, attention is focused on the calc-silicate mineral suite, which is comprised of the components $\mathrm{CaO}-\mathrm{Na}_{2} \mathrm{O}-\mathrm{Al}_{2} \mathrm{O}_{3}-\mathrm{SiO}_{2}-\mathrm{H}_{2} \mathrm{O}-\mathrm{CO}_{2}$. Although potassium may play an important role in some of these mineral phases, particularly in zeolites where it may substitute for $\mathrm{Na}$ and $\mathrm{Ca}$, it was not considered in this study because it is generally low in abundance in minerals that are characteristically part of the calc-silicate series in basaltic systems.

The minerals of interest in the calc-silicate system for the purposes of this study are the zeolites, prehnite, calcite and zoisite-clinozoisite (which are proxies in this study for epidote). This system was selected for detailed consideration because it is the most thoroughly characterised for low-grade mineral development. These minerals possess well-characterised structures and compositions. In addition, there has been a long history of research in the geochemical community to derive thermodynamic data for phases in this system (Liou 1971; Glassley 1974; Frey et al. 1991; Neuhoff et al. 1997, 2002; Fridriksson et al. 2001; Neuhoff \& Bird 2001). Although of immense importance in determining relative conditions in shallow $(<3000 \mathrm{~m})$, low temperature $\left(<150^{\circ} \mathrm{C}\right)$ systems, the clay minerals and chlorites exhibit such structural and compositional complexity that the thermodynamic data available for modelling their behaviour remain inadequate. For that reason, they are not considered further in this report, although work continues on them.

Consideration of the calc-silicate system also eliminates complexities that arise due to the effects of variable oxygen partial pressures, which can dramatically influence the stability of iron-bearing mineral phases. Hence, chlorites, smectites, $\mathrm{Fe}-\mathrm{oxy} / \mathrm{hydroxides}$ and related phases are not considered here. Two exceptions are considered in this paper. Pumpellyite, which is noted in several other studies and documented as a mineral phase of limited distribution at Lopra-1/1A, is considered here as part of the para- genetic assemblage, but does not play an important role in establishing the conclusions presented later. Prehnite is also considered here and does possess limited solid solution with an $\mathrm{Fe}^{3+}$ end member. Measured mole fractions in a limited suite of analysed prehnites (unpublished data 1999 , R. Waagstein) average 0.08 , with a range from 0.00 to 0.20 for 18 samples. Rose $\&$ Bird (1987) have shown that solid solution of as little as $10 \%$ of the Fe end member in Al-rich prehnite can significantly affect prehnite stability. Although the majority of prehnites analysed in the Lopra-1/1A rocks fall below this value, the impact of this effect must be borne in mind and is discussed later in this paper.

Although the stability fields of many of these minerals are reasonably well established for their ideal compositional end-members, each of these minerals belongs to a solid solution series. Generally, there are very little or no quantitative data available regarding the actual compositions of mineral phases in the low-grade rocks described in the referenced reports. In addition, thermodynamic mixing properties of the solid solutions are generally not available. Hence, when comparing stability relationships from one locality to another, it must be borne in mind that uncertainties of unknown magnitude are inherent in the comparison due to possible differences in the compositions of the minerals.

\section{Thermodynamic calculations}

Once mineral assemblages and distributions were compiled, the sensitivity of mineral development to thermal conditions and composition of coexisting fluids was modelled. This effort was undertaken because textural and compositional properties of these secondary minerals attest to the importance of mass transport involving carbonate-bicarbonate-bearing aqueous fluids. The thermodynamic properties of such solutions influence strongly the stability fields of the minerals and can thus be an additional means of placing limits on the physical conditions at the time of mineral growth.

The calculations employed the aqueous speciation/reaction progress software EQ3/6 (Wolery \& Daveler 1992), using the .com database. The modelling was accomplished by performing speciation calculations over a range of temperatures and compiling the affinities of the possible solid phases that may develop in this system. Affinity here is defined as:

$$
\mathrm{A}=2.303 \mathrm{RT} \log (\mathrm{Q} / \mathrm{K})
$$

where $\mathrm{A}$ is the affinity (in calories), $\mathrm{R}$ is the universal gas 


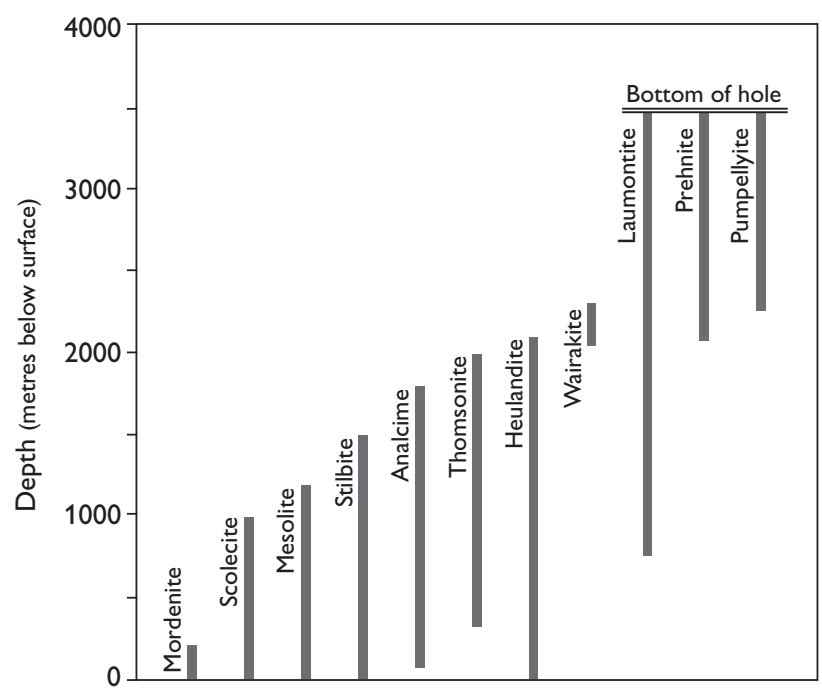

Fig. 1. Summary of depth distributions for minerals reported in the Lopra-1/1A samples (compiled from Jørgensen 1984, fig. 4; 1997, fig. 1). Zero depth corresponds to the ground surface at the drill site. The bottom of the well is indicated. Minerals are arranged along the horizontal axis in a sequence of increasing depth to the right. The depth intervals correspond to the reported occurrences where the individual minerals are most abundant. In some instances, spot occurrences of minerals occur outside the indicated intervals. Such occurrences can result from local variations in rock or fluid chemical conditions, or the consequences of locally controlled reaction kinetics, and are not plotted here.

constant (1987 calories/mole-degree Kelvin), T is temperature (Kelvin), Q is the activity product for the relevant species in the applicable hydrolysis reaction and $\mathrm{K}$ is the equilibrium constant for that same reaction. Affinities greater than zero identify mineral phases that are supersaturated in the water at the specified conditions and affinities less than zero identify mineral phases that are undersaturated for those same conditions. Positive affinities thus correlate with minerals that would be expected to precipitate from solution or form from mineral reactions in the rock, whereas negative affinities indicate that the respective mineral phase will dissolve, if present.

Particular attention was given to the development of prehnite since its compositional variability is less than that of the zeolites and its thermodynamic properties are better constrained. The affinities were calculated assuming in all cases that the system was saturated in quartz, laumontite and albite, since these phases coexist with prehnite (see below). These solids were used to constrain the activities of aqueous $\mathrm{SiO}_{2}, \mathrm{Al}^{3+}$ and $\mathrm{Na}^{+}$, respectively. The same simulations were repeated assuming that calcite was present as a control for $\mathrm{Ca}^{++}$activity to determine the sensitivity of the results to this change in the system constraints. At the beginning of all of the simulations, it was assumed that the hydrogen ion activity was near neutral at the temperature considered. The initial fluid composition (a dilute, neutral-pH water at the temperature considered) was not in equilibrium with the constraining mineral phases but, for each simulation, was allowed to evolve toward equilibrium with the constraining mineral phases. The equilibrium fluid composition that evolved thus represented the composition of an aqueous fluid in equilibrium with the constraining phases and was the beginning point for further simulations that considered the effects of temperature and other compositional variables.

The sensitivity of the results to variations in total $\mathrm{Cl}^{-}$ and $\mathrm{HCO}_{3}{ }^{-}$was also considered. In this case, the simulations were conducted for $\mathrm{Cl}^{-}$concentrations between 14 $\mathrm{mg} / \mathrm{l}$ and $14.410 \mathrm{mg} / \mathrm{l}$, and $\mathrm{HCO}_{3}{ }^{-}$concentrations between $10 \mathrm{mg} / \mathrm{l}$ and $1000 \mathrm{mg} / \mathrm{l}$. This range of values was selected because it encompasses the vast majority of water compositions from hydrothermal systems around the world (see compilations and discussions in Roedder 1972; Ellis \& Mahon 1977; Arnorsson et al. 1983; Fournier 1985).

\section{Results}

The depth intervals over which individual minerals occur at the Lopra-1/1A site are summarised in Fig. 1. Noteworthy in this compilation is that the progression with depth of the zeolite sequence is consistent with that from other localities (see summaries below under 'Compiled data'), and that epidote does not occur, even at the deepest levels. Also of significance is that most of the minerals persist over depth intervals that exceed significantly any other reported occurrence for that mineral.

\section{Compiled data}

The published temperature-depth data compiled from Iceland (Kristmannsdóttir \& Tomassón 1976), Japan (Seki et al. 1969; Boles 1981), Cerro Prieto (Bird et al. 1984), Wairakei (Steiner 1977) and Toa Baja (Cho 1991) are shown in Figs 2-4. For each location, the depth interval over which a mineral occurs is indicated by connected symbols that link the high and low temperature and depth points that define the extent of the mineral phase.

Figures 2-4 also show the depth intervals over which mesolite, stilbite, heulandite, laumontite and prehnite occur in the Lopra-1/1A samples (Jørgensen 1984, 1997). The Lopra-1/1A depth-temperature relationships were constrained to be consistent with the following criteria: 


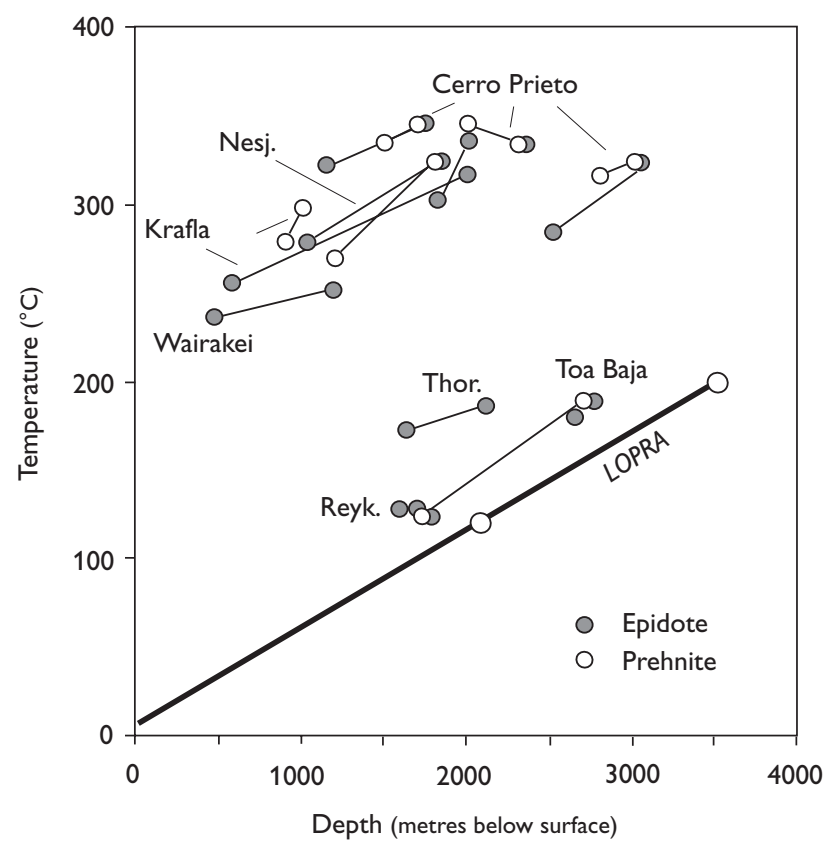

Fig. 2. Temperature-depth distributions reported from active thermal systems for the zeolites chabazite, scolecite-mesolite, mordenite, stilbite and heulandite. Lines between points indicate the temperature-depth intervals over which the minerals are reported to occur. Data sources are: Kristmannsdóttir \& Tomassón 1976 for Iceland; Seki et al. 1969 and Boles 1981 for Japan; Bird et al. 1984 for Cerro Prieto, Baja California; Steiner 1977 for Wairakei, New Zealand; Cho 1991 for Toa Baja, Puerto Rico. The solid line labelled LOPRA is the geothermal gradient derived in Fig. 2, with the depth intervals for Lopra mesolite, stilbite and heulandite indicated. Thor., Thorlakshofn, Iceland; Reyk., Reykjavik, Iceland; Nesj., Nesjavellir, Iceland.

1. Coexistence of analcime and albite is constrained by Cho (1991) to temperatures less than $c .120^{\circ} \mathrm{C}$. Since albite is ubiquitous in the Lopra-1/1A volcanics, the maximum depth occurrence for analcime $(c .1850 \mathrm{~m})$ is assumed to mark the $c .120^{\circ} \mathrm{C}$ isotherm.

2. Laumontite coexisting with prehnite is constrained to temperatures less than $160^{\circ} \mathrm{C}$ (Varna 1989). Since laumontite and prehnite occur together over a depth of more than $1000 \mathrm{~m}$ and extend to the bottom of the Lopra-1/1A hole, this constraint would place the base of the studied sequence at temperatures less than $160^{\circ} \mathrm{C}$.

3. Epidote is considered to require minimum temperatures for development of $200^{\circ} \mathrm{C}$ (Bird et al. 1984). The exception to this would be systems rich in $\mathrm{Fe}^{3+}$ (Varna 1989), which the Lopra-1/1A basalts are not. Epidote is not reported within the Lopra-1/1A rocks, hence the bottom-hole temperature must be less than $200^{\circ} \mathrm{C}$.

4. Pumpellyite requires temperatures in excess of $125^{\circ} \mathrm{C}$ for stable growth (Evarts \& Schiffman 1983; Bevins

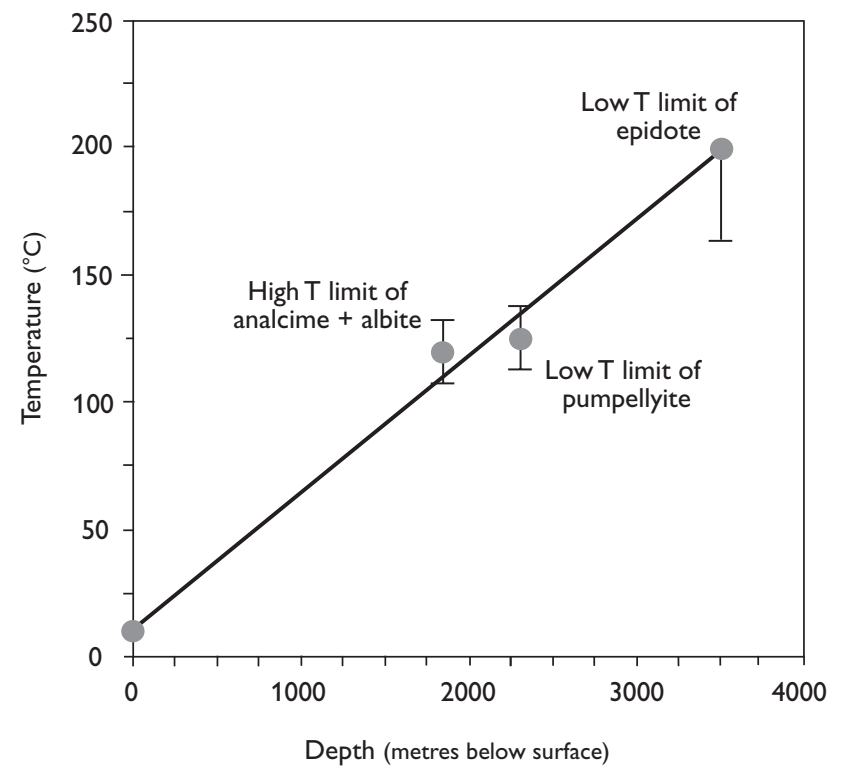

Fig. 3. Temperature-depth distribution for laumontite and prehnite. Laumontite occurrences are from Iceland, Japan and Toa Baja, and prehnite from Iceland, Toa Baja and Cerro Prieto (see Fig. 3 for references and abbreviations). Also shown for comparison is the inferred temperature-depth distribution for the same Lopra minerals along the derived geothermal gradient (Fig. 2).

et al. 1991). The first appearance of pumpellyite is at a depth of $c .2300 \mathrm{~m}$, thus constraining the $125^{\circ} \mathrm{C}$ isotherm to be near this depth.

These observations were used to construct a palaeogeotherm (Fig. 3). In developing this palaeogeotherm, points 1 (the constraint on analcime and albite coexistence) and 4 (the minimum temperature for pumpellyite development) were accepted without qualification. It was also assumed that the mean annual surface temperature was $10^{\circ} \mathrm{C}$ and that the bottom-hole temperature was $c .200^{\circ} \mathrm{C}$. The $200^{\circ} \mathrm{C}$ bottom-hole temperature, which exceeds the $160^{\circ} \mathrm{C}$ constraint inferred from coexistence of prehnite and laumontite (point 2), was used to assure a conservative estimate of maximum thermal conditions and represents a compromise between points 2 and 3 . In other words, the temperature gradient developed by this approach will overestimate maximum likely thermal conditions.

The resulting geothermal gradient is linear. Least squares regression of the data points gives a correlation of fit of 0.9949 and a gradient of $0.05^{\circ} \mathrm{C} / \mathrm{m}$, or $50^{\circ} \mathrm{C} / \mathrm{km}$.

Using this geothermal gradient, the depth intervals for mesolite, stilbite and heulandite were plotted to be consistent with the permissible measured distance over which these minerals occur. Laumontite and prehnite were placed to be consistent with the implied thermal gradient and temperature constraints, as described above. 


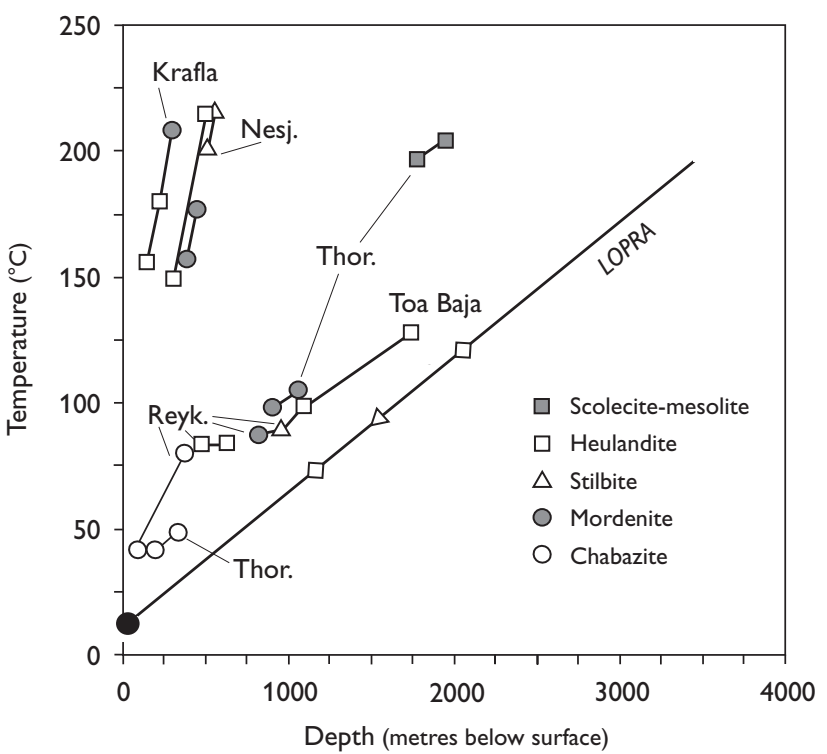

Fig. 4. Temperature-depth distribution for prehnite and epidote. Epidote occurrences are from Iceland, Cerro Prieto, Toa Baja and Wairakei (see Fig. 3 for references). Also shown is the inferred temperature-depth distribution for Lopra prehnite along the derived geothermal gradient (Fig. 2).

This reconstruction provides a conservative estimate of the temperature gradient only if the extent of surface erosion since mineral development is small and if there has been minimal tectonic rotation of the volcanic sequence. The consequence of these points is elaborated on below. The following observations are significant for reconstructing conditions recorded in the Lopra-1/1A samples.

1. The zeolite group of minerals is stable at temperatures throughout the range $40^{\circ} \mathrm{C}$ to $210^{\circ} \mathrm{C}$ (Figs 2-4). The only reported occurrence of zeolites at higher temperatures is from the Wairakei, New Zealand, geothermal field, where wairakite is stable at temperatures of $240^{\circ} \mathrm{C}$ to $250^{\circ} \mathrm{C}$, where it coexists with epidote. This is not an assemblage reported from Lopra-1/1A. The corresponding geothermal gradients for Wairakei range from a high of $>400^{\circ} \mathrm{C} / \mathrm{km}$ to a low of $c .40^{\circ} \mathrm{C} / \mathrm{km}$. The highest temperature gradients require active volcanic/ magma systems and are not typical of most environments. Nevertheless, the stability relationships for minerals from these systems provide useful information for defining thermal stability limits for the minerals being considered. It should be noted, too, that the higher temperature conditions likely reflect convective hydrothermal environments with highly non-linear geothermal gradients. Inevitably, lower geothermal gradients result in a particular mineral being observed over a much longer interval. This then implies that, for a

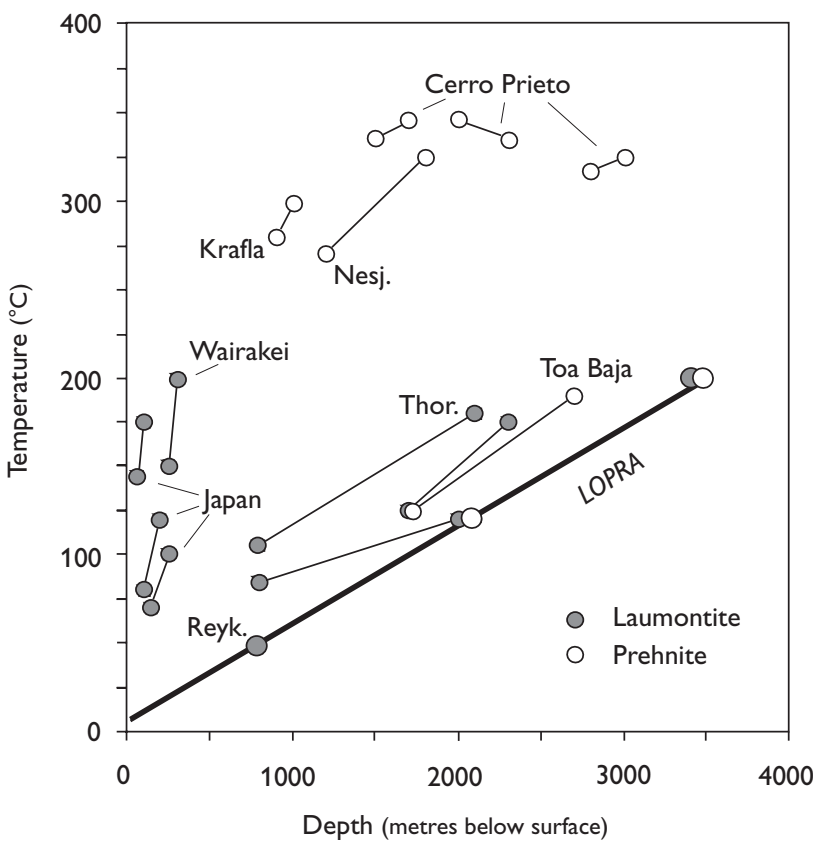

Fig. 5. Temperature constraints for the indicated mineral associations or occurrences. See text for sources and assumptions. The straight line is a least squares fit to the data points. The uncertainty bars for the analcime + albite 'out' and the pumpellyite 'in' data points span $25^{\circ} \mathrm{C}$, and are presented only as an inferred, reasonable uncertainty envelope, in the absence of any available analytical data. The bar associated with the epidote lower $\mathrm{T}$ limit indicates the range of possible bottom hole metamorphic temperatures, based on the alternative constraint that the maximum temperature for laumontite coexisting with prehnite is $160^{\circ} \mathrm{C}$. See text for further details.

given combination of rock- and fluid-compositional characteristics, the lower the temperature gradient, the greater will be the depth range of a borehole over which a particular mineral will occur.

2. Although local conditions (such as rock composition, coexisting fluid chemistry, local gas chemistry) at each site determine the exact zeolite sequence, the sequence of minerals generally follows one in which zeolites with high contents of molecular water (e.g. chabazite, scolecite, mesolite) are progressively replaced by zeolites with lower contents of molecular water (e.g. heulandite and laumontite) at higher temperatures.

3. In all cases considered, the assemblage prehnite-laumontite formed near the upper stability field of the zeolites and prior to the appearance of epidote. The temperature range for stable laumontite is in the range $70^{\circ} \mathrm{C}$ to $200^{\circ} \mathrm{C}$. As noted by Surdam (1973) and Bird et al. (1984), prehnite-laumontite relationships are sensitive to the activity ratio $[\mathrm{Ca}++] /[\mathrm{H}+]^{2}$ in the fluid 
phase. Variation in fluid chemistry is thus the likely cause for the broad temperature interval observed for laumontite stability.

4. In all cases, prehnite first forms at lower temperatures than epidote. However, both occur within the higher temperature range of the zeolites and are stable beyond the zeolite field (Fig. 4). Prehnite, for example, is reported to be stable in the temperature range $125^{\circ} \mathrm{C}$ to $340^{\circ} \mathrm{C}$ in the reports referenced in this study. This temperature interval is the same as reported for the stable presence of epidote, although the lower temperature occurrences of epidote are in systems that have high $\mathrm{Ca}^{++}$and $\mathrm{Fe}^{3+}$ activity.

The mineral sequence recorded in the Lopra-1/1A well (Fig. 1) is typical of that reported in other geothermal systems. The zeolite sequence follows the pattern of generally decreasing molecular water content with increasing depth, reflecting the impact of elevated temperatures at deeper levels in the borehole. This observation is generally consistent with the view that the thermal history experienced by these basalts was relatively simple.

The highest temperature mineral assemblage that has developed is the prehnite-laumontite assemblage that is reported from the depth interval $2100 \mathrm{~m}$ to $3500 \mathrm{~m}$. This assemblage clearly must extend beyond the bottom of the hole to an unknown depth. Nevertheless, the $1400 \mathrm{~m}$ length of this assemblage is one of the longest such intervals reported anywhere in the world. By comparison, the Toa Baja prehnite-laumontite zone, thelongest interval reported for these minerals, has a total length of about $850 \mathrm{~m}$, and a geothermal gradient of between $50^{\circ} \mathrm{C} / \mathrm{km}$ and $70^{\circ} \mathrm{C} /$ $\mathrm{km}$. The inferred temperature interval over which the prehnite-laumontite association formed at Lopra-1/1A is inferred to be approximately $120^{\circ} \mathrm{C}$ to $200^{\circ} \mathrm{C}$.

Epidote does not occur in any of the samples from the Lopra-1/1A suite. Figure 4 shows that this would require the bottom hole temperature not to exceed $c .250^{\circ} \mathrm{C}$ to $350^{\circ} \mathrm{C}$, which appears to be the temperature interval over which epidote is consistently observed, although lower temperature occurrences have been reported, for example at Thorlakshofn and Reykjavik in Iceland and at Toa Baja. As noted above, it is inferred that epidote will not form at temperatures less than $c .200^{\circ} \mathrm{C}$ under conditions of low to moderate $\mathrm{Fe}^{3+}$ and $\mathrm{Ca}^{++}$activity. It is thus assumed that the Iceland and Toa Baja occurrences reflect chemical environments that satisfy these conditions.

The Vestmanna-1 hole, which was also part of the drilling programme (Jørgensen 1984, 1997) contains mineral assemblages typical of the shallowest levels of hydrother- mal systems and overlap those of the Lopra-1/1A sequence. If these mineral assemblages developed simultaneously, the computed geothermal gradient for the Lopra-1/1A sequence would have to be considered a maximum. However, uncertainty exists regarding whether these mineral sequences for these two drill holes are coeval.

\section{Thermodynamic calculations}

A suite of thermodynamic calculations, using the code EQ3/6, was completed to determine the chemical conditions in the fluid phase that would constrain development of the mineral assemblage prehnite-laumontite-quartzalbite-calcite found in the wells. In these calculations, it was assumed that sodium, aluminium, calcium and silica aqueous concentrations are constrained by equilibrium with albite, laumontite, calcite and quartz, respectively. The calculated saturation state of the solution with respect to prehnite was monitored, as temperature and bicarbonate and chloride concentrations were changed. $\mathrm{CO}_{2}$ partial pressure was allowed to evolve in response to the equilibrium conditions and monitored to assure that it remained within 'real world' bounds. By noting the temperature

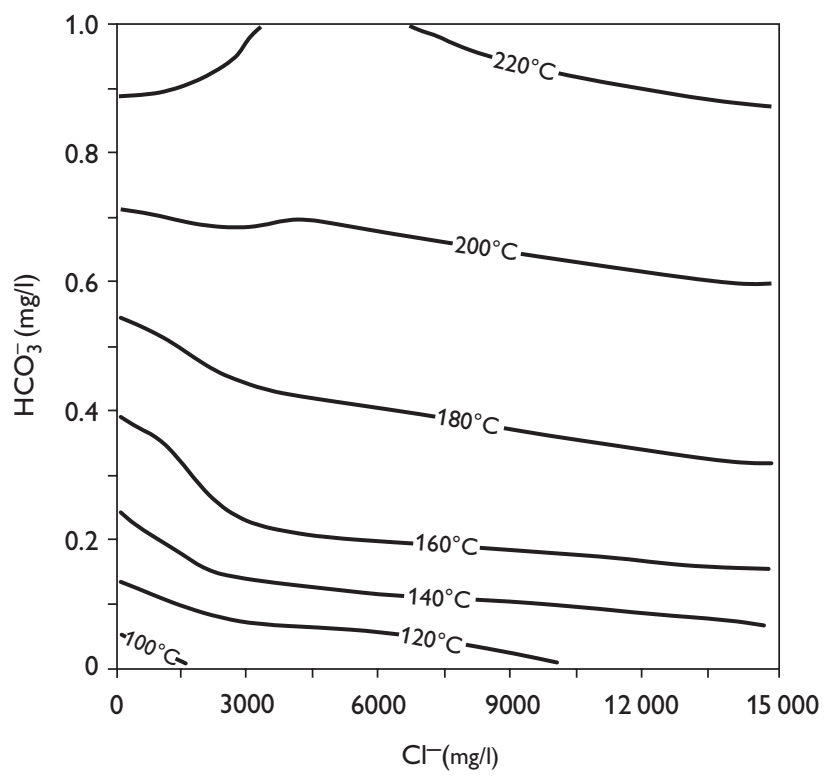

Fig. 6. Calculated lower thermal stability limit of prehnite coexisting with albite-calcite-quartz-laumontite, as a function of $\mathrm{HCO}_{3}{ }^{-}$and $\mathrm{Cl}^{-}$concentrations in the coexisting aqueous phase. Contours on the stability limit surface are labelled in degrees centigrade. The mineral assemblage albite-calcite-quartz-laumontite was used in the calculations because it represents the highest temperature mineral assemblage observed in the bottom of the Lopra-1/1A hole. 
and bicarbonate and chloride concentrations at which the solution became saturated in prehnite, it is possible to delineate those conditions that bound the stability field for the prehnite-bearing mineral assemblage.

The results of the calculations are presented in Fig. 6, which shows the contoured temperature surface for the stability of prehnite coexisting with a bicarbonate-chloride solution in equilibrium with laumontite-calcitequartz-albite. The contours map the minimum temperature required for prehnite stability in this system. It must be emphasised that the exact location of these contours is somewhat imprecisely known, due to uncertainty in the thermodynamic data. The uncertainty in the bicarbonate values is approximately $\pm 50 \mathrm{mg} / \mathrm{l}$, based on interpolations between simulations. These results show that prehnite stability is only slightly sensitive to the solution salinity (as indicated by the effect of variation in the chloride ion, $\mathrm{Cl}^{-}$), but is very sensitive to the solution carbonate/ bicarbonate concentration. This behaviour reflects the strong coupling between these variables and Ca speciation and $\mathrm{pH}$. The more concentrated the solution in terms of carbonate/bicarbonate, the higher the temperature necessary to achieve prehnite stability. These calculations suggest that the wide range of prehnite thermal stability observed in natural systems (Figs 2, 5) is due, at least in part, to differences in fluid composition from one location to another. This probably is true for other minerals in this calc-silicate suite as well. As documented by Rose $\&$ Bird (1987), the redox state and iron content of the fluid will also be an important variable in controlling prehnite stability, due to the effect of $\mathrm{Fe}^{3+}$ substitution for $\mathrm{Al}$ in the prehnite structure.

Salinities determined from a preliminary fluid inclusion study of the Lopra-1/1A samples (Konnerup-Madsen 1998) gave $\mathrm{Cl}^{-}$concentrations of between 0.167 and 1.49 equivalent weight per cent $\mathrm{NaCl}$, which is approximately 1000 to $9000 \mathrm{mg} / \mathrm{l} \mathrm{Cl}^{-}$. The analytical bicarbonate ion concentrations with this salinity in natural solutions in hydrothermal systems and at these temperatures and pressures are usually in the range of 200 to $800 \mathrm{mg} / \mathrm{l}$ (see compilations and discussions in Roedder 1972; Ellis \& Mahon 1977; Arnorsson et al. 1983; Fournier 1985) although the actual $\mathrm{HCO}_{3}{ }^{-}$concentrations in the reservoirs will be lower than this value and be controlled by $\mathrm{CO}_{2}$ fugacity. This implies (Fig. 6) that the mineral association prehnite-laumontite-calcite-quartz formed at temperatures within the range of approximately $140^{\circ} \mathrm{C}$ to $205^{\circ} \mathrm{C}$. This temperature interval is contained within the range of prehnite stability noted in other hydrothermal systems (see Figs 2, 5) and is thus consistent with natural occurrences of this assemblage. It is also broadly consistent with the inference from phase relationships described above, in which it is suggested that this assemblage spans the temperature interval of approximately $120^{\circ} \mathrm{C}$ to $200^{\circ} \mathrm{C}$.

\section{Discussion and conclusions}

Secondary mineral assemblages documented for the basalts recovered from the Lopra-1/1A well are similar to those reported from other hydrothermal systems. Both the specific mineral occurrences and the relative sequence of mineral stabilities define a systematic distribution that records increasing temperature with depth. The absolute length of individual mineral zones, however, is greater than at other well-documented sites, and suggests that the geothermal gradient at the time of mineral development was low. The mineral associations, complemented by thermodynamic calculations of fluid-rock equilibrium relationships, suggest that the temperature at the bottom of the well did not exceed $200^{\circ} \mathrm{C}$, implying a maximum thermal gradient of $50^{\circ} \mathrm{C} / \mathrm{km}$ (assuming a surface temperature in the range of 10 to $25^{\circ} \mathrm{C}$ ). This gradient was constructed based on the assumption that the mineral zones are approximately horizontal. There is currently no structural data available to suggest this assumption is far from accurate, but it remains to be established conclusively. Furthermore, it is also assumed that the total stratigraphic thickness at the time of mineral development did not greatly exceed that exposed and inferred today. This assumption is reasonable, based on the correlations established by Larsen et al. (1999) between the East Greenland volcanic complex and the Faroe Islands. The correlations indicate that the current thickness of basalts in the Faroe Islands is probably close to that which was originally erupted.

It has previously been suggested that mineral development may have occurred in several discrete episodes (Jørgensen 1984, 1997). Such an interpretation makes more complex the sequence and timing of mineral growth and may change the absolute depth intervals over which specific mineral associations formed within a given time period. This, in turn, would require reconsideration of the temperature history since such an observation could result only in shorter absolute depth intervals for each mineral development period. In this scenario, the currently observed distribution of minerals would represent the sum of the depth intervals over which an individual mineral formed at different time periods, assuming that no single episode of mineral development obliterated evidence of previous distributions of secondary mineral development. Nevertheless, the conclusion that the bottom hole tem- 
perature did not exceed $200^{\circ} \mathrm{C}$ would still be valid, since that is based on the mineral association calcite-laumontite-prehnite-quartz, the temperature limit of which is constrained by laumontite and prehnite thermal stability and fluid composition effects.

Comparison of the derived geothermal gradient in the Faroes with those reported for the Atlantic margin region north of the United Kingdom and in East Greenland demonstrates a striking consistency that constrains evolution of the geothermal history in this region. Green et al. (1999) used fission track data from apatites as well as vitrinite reflectance data from a series of wells in the eastern North Atlantic Province to determine palaeogeothermal gradients. They reported geothermal gradients of between $35^{\circ} \mathrm{C} / \mathrm{km}$ and $90^{\circ} \mathrm{C} / \mathrm{km}$, with the vast majority of the region falling within the lower portion of the range. Neuhoff et al. (1997) concluded that the zeolite facies metamorphism that affected East Greenland flood basalts during initial opening of the northern North Atlantic resulted from recrystallisation associated with a geothermal gradient of $40 \pm 5^{\circ} \mathrm{C} /$ $\mathrm{km}$. The regional heat flow they derived from this conclusion is consistent with that reported from a study of metamorphic recrystallisation (Manning et al. 1993). All of these values effectively bracket the inferred geothermal gradient in the Faroe Islands and argue for early development of relatively low geothermal gradients that persisted for some time in these regions. These results, and those of Larsen et al. (1999), provide conceptual constraints on models of the thermal evolution of this part of the northern North Atlantic province during early continental separation and basin development and argue for regions of low geothermal gradients that were not overprinted by later high heat-flow periods.

As a word of caution, it should be noted that these conclusions are based on the simplifying assumption that linear geothermal gradients existed during mineral growth in this region. There is substantial evidence in geothermal systems, however, that complex geothermal gradients commonly develop, such that temperature reversals or near isothermal conditions may develop in response to the local thermal-hydrological regime, particularly in environments dominated by convection-driven fluid flow. Although such features usually develop in regions of high heat flow and are not characteristic of environments such as the Faroe Islands region where heat flow is inferred to be low, evidence is currently inadequate to rule out this possibility conclusively. To evaluate the extent to which such behaviour occurred in the Faroe Islands volcanic province, a more detailed examination of mineral composition characteristics and distributions would be required, coupled with a more detailed modelling effort.

\section{Acknowledgements}

Regin Waagstein kindly provided timely access to thin sections, mineral composition data and mineral distribution data, as well as informative discussions. His assistance greatly aided this effort. Extensive comments from Dennis Bird and Bruce Christenson led to significant improvements in earlier versions of the manuscript, and are gratefully acknowledged. The editorial wisdom of James A. Chalmers significantly improved the presentation and style of this paper.

\section{References}

Arnorsson, S., Gunnlaugsson, E. \& Svavarsson, H. 1983: The chemistry of geothermal waters in Iceland. II. Mineral equilibria and independent variables controlling water compositions. Geochimica et Cosmochimica Acta 47, 547-566.

Bevins, R.E., Rowbotham, G. \& Robinson D. 1991: Zeolite to prehnite-pumpellyite facies metamorphism of the late Proterozoic Zig-Zag Dal basalt formation, eastern North Greenland. Lithos 27, 155-165.

Bird, D., Schiffman, P., Elders, W.A., Williams, A.E. \& McDowell, S.D. 1984: Calc-silicate mineralization in active geothermal systems. Economic Geology 79, 671-695.

Boles, J.R. 1981: Zeolites in low grade metamorphic rocks. In: Mumpton, F.A. (ed.): Mineralogy and geology of zeolites. Mineralogical Society of America Reviews in Mineralogy 4, 103135.

Cho, M. 1991: Zeolite to prehnite-pumpellyite facies metamorphism in the Toa Baja drill hole, Puerto Rico. Geophysical Research Letters 18, 525-528.

Ellis, A.J. \& Mahon, W.A.J. 1977: Chemistry and geothermal systems, 392 pp. New York: Academic Press.

Evarts, R.C. \& Schiffman, P. 1983: Submarine hydrothermal metamorphism of the Del Puerto ophiolite, California. American Journal of Science 283, 289-340.

Fournier, R.O. 1985: Continental scientific drilling to investigate brine evolution and fluid circulation in active hydrothermal systems. In: Raleigh, C.B. (ed.): Observation of the continental crust through drilling I, 98-122. Berlin: Springer-Verlag.

Frey, M., de Capitani, C. \& Liou, J.G. 1991: A new petrogenetic grid for low-grade metabasites. Journal of Metamorphic Geology 9, 497-509.

Fridriksson T., Neuhoof, P.S., Arnorsson, S. \& Bird, D.K. 2001: Geological constraints on the thermodynamic properties of the stilbite-stellerite solid solution in low-grade metabasalts. Geochimica et Cosmochimica Acta 65, 3993-4008.

Glassley, W. 1974: A model for phase equilibria in the prehnitepumpellyite facies. Contributions to Mineralogy and Petrology 43, 317-332.

Green, P.F., Duddy, I.R., Hegarty, K.A. \& Bray, R.J. 1999: Early 
Tertiary heat flow along the UK Atlantic margin and adjacent areas. In: Fleet, A.J. \& Boldy, S.A.R. (eds): Petroleum geology of Northwest Europe, Proceedings of the 5th Conference, 349357. London: Geological Society.

Hedenquist, J.W. 1990: The thermal and geochemical structure of the Broadlands-Ohaaki geothermal system, New Zealand. Geothermics 19, 151-185.

Jørgensen, O. 1984: Zeolite zones in the basaltic lavas of the Faeroe Islands. In: Berthelsen, O., Noe-Nygaard, A. \& Rasmussen, J. (eds): The Deep Drilling Project 1980-1981 in the Faeroe Islands. Annales Societatis Scientiarum Faroensis. Supplementum 9, 71-91.

Jørgensen, O. 1997: Zeolites and other secondary minerals in cavities and veins, Lopra-1/1A well, Faroe Islands, 1996, 8 pp. + plates. Unpublished report, Technical studies prepared for Dansk Olie og Gasproduktion A/S, Copenhagen, Denmark (in archives of Geological Survey of Denmark and Greenland, GEUS Report File 26129).

Konnerup-Madsen, J. 1998: A preliminary examination of fluid inclusions in vug and fracture-filling quartz and calcite from Lopra-1/1a, Faroe Islands, 5 pp. Unpublished report, Geological Survey of Denmark and Greenland, Copenhagen.

Kristmannsdóttir, H. \& Tomassón, J. 1976: Zeolite zones in geothermal areas in Iceland. In: Sand, L.B. \& Mumpton, F.A. (eds): Natural zeolites; occurrence, properties, use, 277-284. Oxford: Pergamon Press.

Larsen, L.M., Waagstein, R., Pedersen, A.K. \& Storey, M. 1999: Trans-Atlantic correlation of the Palaeogene volcanic successions in the Faeroe Islands and East Greenland. Journal of the Geological Society (London) 156, 1081-1095.

Liou, J.G. 1971: Synthesis and stability relations of prehnite, $\mathrm{Ca}_{2} \mathrm{Al}_{2} \mathrm{Si}_{3} \mathrm{O}_{10}(\mathrm{OH})_{2}$. American Mineralogist 56, 507-531.

Manning, C.E., Ingebritsen, S.E. \& Bird, D.K. 1993: Missing mineral zones in contact metamorphosed basalts. American Journal of Science 293, 894-938.

Neuhoff, P.S. \& Bird, D.K. 2001: Partial dehydration of laumontite; thermodynamic constraints and petrogenetic implications. Mineralogical Magazine 65, 59-70.

Neuhoff, P.S., Watt, W.S., Bird, D.K. \& Pedersen, A.K. 1997: Timing and structural relations of regional zeolite zones in basalts of the East Greenland continental margin. Geology 25, 803-806.
Neuhoff, P.S., Kroeker, S., Du, L.S., Fridriksson, T. \& Stebbins, J.F. 2002: Order/disorder in natrolite group zeolites: a ${ }^{29} \mathrm{Si}$ and ${ }^{27} \mathrm{Al}$ MAS NMR study. American Mineralogist 87, 1307-1320.

Neuhoff, P.S., Stebbins, J.F. \& Bird, D.K. 2003: Si-Al disorder and solid solutions in analcime, chabazite, and wairakite. American Mineralogist 88, 410-423.

Neuhoff, P.S., Hovis, G.L., Balassone, G. \& Stebbins, J.F. 2004: Thermodynamic properties of analcime solid solutions. American Journal of Science 304, 21-66.

Roedder, E. 1972: Composition of fluid inclusions. In: Data of geochemistry. U.S. Geological Survey Professional Paper 400JJ, 164 pp.

Rose, N.M. \& Bird, D.K. 1987: Prehnite-epidote phase relations in the Nordre Aputiteq and Kruuse Fjord layered gabbros, East Greenland. Journal of Petrology 28, 1193-1218.

Seki, Y., Onuki, H., Okumura, K. \& Takashima, I. 1969: Zeolite distribution in the Katayama geothermal area of Japan. Japanese Journal of Geology and Geography 40, 63-79.

Steiner, A. 1977: The Wairakei geothermal area, North Island, New Zealand: its subsurface geology and hydrothermal rock alteration. New Zealand Geological Survey Bulletin 90, 136 pp.

Surdam, R.C. 1973: Low-grade metamorphism of tuffaceous rocks in the Karmutsen Group, Vancouver Island, British Columbia. Geological Society of America Bulletin 84, 1911-1922.

Varna, C.L. 1989: Mineral reactions and controls on zeolite-facies alteration in sandstones of the Central Transantarctic Mountains, Antarctica. Journal of Sedimentary Petrology 59, 688703.

Waagstein, R., Guise, P. \& Rex, D. 2002: K/Ar and 39Ar/40Ar whole-rock dating of zeolite facies metamorphosed flood basalts: the upper Paleocene basalts of the Faroe Islands. In: Jolley, D.W. \& Bell, B.R. (eds): The North Atlantic Igneous Province: stratigraphy, tectonic, volcanic and magmatic processes. Geological Society Special Publication (London) 197, 219-252.

Wolery, T.J. \& Daveler, S.A. 1992: EQ6, A computer program for reaction path modeling of aqueous geochemical systems: theoretical manual, user's guide, and related documentation. Lawrence Livermore National Laboratory UCRL-MA-110662 Part IV, 338 pp. 